\title{
ADVANCES IN ENDOSCOPIC DIAGNOSIS OF COLORECTAL CANCER
}

\author{
Maša Čavlina, Nadan Rustemović \\ University Hospital Centre Zagreb, Department of Gastroenterology and \\ Hepatology, Zagreb, Croatia.
}

\begin{abstract}
Summary
Colorectal cancer (CRC) is the third most commonly diagnosed malignant tumor and the fourth leading cause of cancer death in the world. Since it is known that most of colorectal cancers arise from adenomatous polyps, screening programmes were developed in order to improve detection of polyps and early diagnosis of carcinoma. Colonoscopy is the gold standard for diagnosis of CRC. Because of its high adenoma missing rates and lower ability to differentiate between benign and malignant lesions novel techniques are being developed in order to improve mucosal visualization, reduce adenoma missing rates and enable in-vivo optical diagnosis. Methods can roughly be divided into three categories, ones that present improved visualization techniques (endoscopes with increased field of view, auxiliary imaging devices, so called addon devices), ones that enable more detail tissue characterization presenting the possibility for virtual biopsy (conventional or virtual chromoendoscopy, confocal laser endomicroscopy and endocytoscopy), and other minimally or non-invasive techniques.

Further investigation is needed, but hopefully these innovations with continuous technical improvement might help to reduce the colorectal cancer incidence and mortality.
\end{abstract}

Keywords: colorectal carcinoma; diagnosis; endoscopy; colonoscopy.

\section{INTRODUCTION}

Colorectal cancer $(\mathrm{CRC})$ is the third most commonly diagnosed malignant tumor and the fourth leading cause of cancer death in the world. According to GLOBOCAN 2012 it accounts for about 1.4 million new cases and almost 700000 deaths in 2012, with highest incidence in high-income countries. The global burden of CRC, according to International Agency for Research on Cancer, is expected to increase by $60 \%$ to more than 2.2 million new cases and 1.1 million cancer deaths by 2030 [1].

Rapid increases in CRC incidence and mortality rates in many medium-to-high human development index (HDI) countries are observed, in particular in those that 
are transitioning to Western lifestyle and have aging populations. On the other side, both incidence and mortality rates in highest indexed human development index (HDI) countries (USA, Australia, West Europe) are stabilizing, even declining [2,3]. These significant geographical variations in trends seem to be due to many factors, economic resources, healthcare structure and infrastructure, educational interventions, availability of organized screening programmes and various screening uptake [4,5]. Since it is known that most colorectal cancers, regardless of etiology arise from adenomatous polyps a proper public health approach is based on preventive measures, the early detection and removal of polyps, and therefore prevention and detection of carcinoma at an early, curable stage [6]. Screening programmes differ markedly between countries and are generally based on non-invasive stool tests detecting microscopic amounts of blood by targeting either haem or human globin and based upon the results selecting patients for colonoscopy $[4,7]$.

Colonoscopy is generally considered the gold standard for the detection of colorectal neoplasia, and several prospective cohort studies have proven colonoscopy (with polypectomy) to be associated with long-term (20-30 years) reduction in CRC mortality by $40-60 \%[8,9]$. Problems arise from its high polyp missing rate (which is with adenoma detection and missing rates one of the main quality asessment tools), invasiveness and a large number of 'unnecessarily performed polypectomies'. Several systematic reviews have shown that polyp missing rates are up to $26 \%$, increasing significantly in smaller size polyps $(<10 \mathrm{~mm})$, flat lesions, in cases of poorly prepared bowel and incomplete examination [10-12]. Also, by using standard colonoscopy procedures that don't provide enough information of the structure of lesions, even small or diminutive polyps with low cancer risk are being resected and examined histologically. Consequently, novel techniques are being developed in order to improve visualization, reduce adenoma missing rates and enable optical diagnosis, either by using several improved observation techniques, auxiliary imaging devices, colonoscopes with increased field of view, or other minimally or noninvasive techniques [13]. An overview of those will be presented in this review.

\section{NOVEL TECHNIQUES IN ENDOSCOPIC DIAGNOSTICS OF COLORECTAL CANCER}

Standard white-light forward viewing colonoscopy with biopsy sampling of lesions suspected as neoplastic and following histopathological analysis are still the gold standard in diagnosis of colorectal cancer. Even though the significant progress has been made to enhance the resolution of white-light endoscopes (development of high-resolution and high-magnification endoscopes by advancing the charge-cou- 
pled devices $(\mathrm{CCD})$ and its complementary technology and therefore enabling the production of signal images with resolution that range from 850000 to more than 1 million pixels and the ability to magnify images up to 150 times) the detection and diagnosis of premalignant lesions, such as adenoma and early-stage carcinoma, remains a great challenge, with high adenoma missing rate and significant number of interval carcinoma [14,15].

Novel methods were therefore developed to overpass anatomical difficulties of the colon, enable more accurate, even microscopic identification of abnormalities in the size, density and shape of crypts and vessels [13,16-18]. They can be roughly divided into three categories, ones that improve overall mucosal examination and increase the polyp detection, those that enable more thorough examination (almost histological) of the detected lesions and minimally invasive techniques.

Techniques developed to improve mucosal observation include those trying to provide more thorough examination of colonic mucosa overpassing the anatomical difficulties of the colon itself either by adding a specific devices on standard colonoscopes or by widening its field of view.

Add-on devices endoscopy consist of attaching a transparent cap or endocuff to the tip of a standard colonoscope before insertion. The role of a cap is to reduce the blind mucosal surface by depressing the haustral folds. One meta-analysis of 16 randomized controlled trials investigating the efficacy of cap-assisted colonoscopy in comparison to standard colonoscopy revealed a slight benefit in polyp detection rate, showing the improvement of polyp detection with shorter caps $(2-4 \mathrm{~mm})$ with the advantage of significantly shorter insertion times [18,19]. Endocuff has two rings of soft, flexible branches that are used to flatten the colonic folds while withdrawing the scope, making the area behing folds more visible. Its efficacy was evaluated in various studies, showing similar or higher adenoma detection rate (ADR) compared to standard colonoscopy [20,21].

Third Eye Retroscope (TER; Avantis Medical Systems) is a retrograde-viewing auxiliary device which is inserted through the colonoscope providing simultaneous retrograde view that complements the forward view of standard colonoscopy. In almost all available studies it has shown significantly higher adenoma detection rate when compared to standard colonoscopy [22]. Because of its long learning curve and need to use a working channel of colonoscope thereby lengthening the procedure Avantis Medical Group has developed its improved version, Third Eye Panoramic, which is a single use video- cap containing two side-viewing lenses fitted onto a standard colonoscope [23].

For the reason that standard colonoscopes have a relatively narrow field of view $\left(140^{\circ}\right)$ efforts that were invested to increase it have resulted in development of wide- 
angle colonoscopes. Full Spectrum Endoscopes are most developed wide-angle colonoscopes that provide a high- resolution image with $330^{\circ}$ field of view. It produces three images that are displayed on three contiguous video monitors and according to by now available studies has presented itself as a promising technique [24].

Baloon colonoscope (NaviAid G-EYE, SMART Medical systems, Israel) uses a baloon that when inflated by the endoscopist can flatten and straighten haustral folds and enhance the visualization. A randomized tandem study published 2015 has shown it to have higher adenoma detection rates when compared to standard colonoscopy [25].

Techniques that enhance tissue characterization and differentiation are developed in the interest of optical diagnosis, therefore to prevent the necessity of a biopsy if the lesion is by high accuracy found benign. Chromoendoscopy is a classic method, developed to enhance tissue characterization, especially in detection of nonpolypoid colorectal neoplasms that are otherwise easily missed. Conventional chromoendoscopy refers to the application of strains of dyes during colonoscopy on the whole colonic mucosa (pancolonic chromoendoscopy) or over a detected lesion [26]. Indigo carmine is a most frequently used contrast dye, pooling in mucosal grooves and depressed areas without being absorbed by the mucosal glands, allowing better characterization of mucosal surface. Pancolonic chromoendoscopy increased the detection of flat and small adenomas when compared to standard endoscopy (SE) in almost all available studies, but because of its longer withdrawal time, long learning curve and costs its routine use appears not to be beneficial for average-risk colorectal cancer screening [27-29]. On the other hand, its routine use in patients at higher risk, with inflammatory bowel disease or known or suspected hereditary syndromes with accelerated carcinogenesis is recommended by European Society of Gastrointestinal Endoscopy (ESGE) [30].

Narrow-spectrum endoscopy is a group of image enhancement techniques also called 'virtual chromoendoscopy'. It relies on using a narrowed part of the available spectral bandwidth. Narrow band imaging (NBI) (Olympus Medical Systems, Tokyo, Japan) was first of the commercially available narrowed-spectrum technologies. It filters leads to the use of ambient light of wave lengths of 440 to $460 \mathrm{~nm}$ and 540 to $560 \mathrm{~nm}$ (peaks of light absorption of haemoglobin) which results in an increased contrast for superficial microvessels and in greater clarity of mucosal surface structures, recognizing the neoplastic tissue by its increased angiogenesis, therefore enabling the optical diagnosis, even predicting deep submucosal invasive carcinoma when using NBI international colorectal endoscopic (NICE) classification $(31,32)$. A large meta-analysis of 56 studies using NBI for optical diagnosis found overall sensitivity to be $91 \%$ (95\% CI $88.6-93 \%$ ), specificity $85.6 \%$ (95\% CI $81.3-89.0 \%$ ) and 
negative predictive value of $82.5 \%$ (95\% CI 75.4-87.9\%) [33]. American Society for Gastrointestinal Endoscopy (ASGE) supports its clinical use for optical diagnosis of diminutive polyps [34]. Flexible spectral imaging color enhancement (FICE, Fujinon Intelligent Chromo Endoscopy; Fujifilm, Tokyo, Japan) is a spectral estimation technique, in which image captured by a video endoscope is then processed according to the most suitable wavelength for examination, adjustable by the user. Even though its adenoma detection rate appears not to be higher in comparison to SE, by following the classification from 2009 based on magnified microvessel patterns (by Texeira et al.) it provides good diagnostic accuracy for colonic polyps [35]. I-SCAN (Pentax, Tokyo, Japan) is another narrow-spectrum endoscopy method. It consists of three enhancement features, surface enhancement sharpening the image, contrast enhancement making depressed areas look more blue and tone enhancement which is a form of digital narrowed-spectrum imaging that has four different types of modification, for vascular pattern assessment, intestine, esophagus and the stomach (36). The use of all narrow-spectrum endoscopy methods using validated classification systems is strongly recommended by ESGE for optical diagnosis of diminutive polyps by appropriately trained endoscopists [30].

Autofluorescence imaging (AFI) is based on real-time detection of fluorescence emitted by tissue molecules and differences in its emission between neoplastic (coloured purple) and non-neoplastic (coloured green) tissue. Results of studies comparing it to white light endoscopy (WLE) are heterogenous, with most encouraging ones reported in a prospective, single-centre randomized controlled trial that compared AFI with transparent hood to WLE, showing significantly higher neoplasm detection rate in the AFI (1.96 v. 1.19, p-0.023) [37].

Blue laser imaging (BLI, Fujifilm) is a system using two different lasers with different wave-lenghts as the light sources. First laser excites the white light phosphor to produce standard white light and other one highlights microvessels and structures of the superficial part of mucous membrane, enabling multiple observations by changing laser intensity. New generation of BLI system (LASEREO, Fujifilm) includes a mixture of short-wavelength narrow-band light and white light. A novel multicentre prospective study found the mean number of polyps and adenoma detected per patient significantly higher when using LASEREO system compared to WLE [38].

Confocal laser endomicroscopy (CLE) and Endocytoscopy (EC, Olympus Co. Ltd) present an emerging technologies, created to allow in vivo imaging of cellular and subcellular details of the gut mucosa and vessels with the idea of enabling a real-time histology [39]. Unlike other narrow spectrum technologies or AFI CLE requires intravenously or topically administered contrast agents (fluorescin sodium 
or acriflavine hydrochloride). Its use appears to be beneficial in decision making once adenoma is detected but it seems not to provide better ADR (40). Endocytoscopy involves a contact light microscopy system on the distal tip of a conventional colonoscope, and by its ability to magnify (80- or 100-fold) makes possible in vivo observation of pit patterns of tumor surfaces (41). As with CLE it requires application of a contrast agent. Its use has been evaluated in several japanese studies and has been proven to be useful in decision making during colonoscopy [42].

Minimally invasive techniques were developed as a response to low acceptance rate for colorectal cancer screening trying to overpass the invasive nature of colonoscopy, its unpleasant perception and possible complications. Colon capsule endoscopy (CCE) is a wireless and minimally invasive technique for imaging the colon. It is a three component system, consisting of an ingestible capsule $(11.6 \times 3.5 \mathrm{~mm} 2)$, sensing system with pads or a belt to attach to the patient and a personal computer workstation with software. In 2009, second generation CCE (CCE-2) with increased accuracy and almost $360^{\circ}$ angle view was developed, enabling higher sensitivity for polyp detection and therefore presenting a promising technology for screening and monitoring of colorectal diseases, particularly in those patients unwilling to undergo colonoscopy or for those in whom it is not technically feasible [43,44]. Virtual endoscopy was developed as a noninvasive technique that relies on rapid high-resolution computed tomography (CT) or magnetic resonance (MR) scanning of the prepared, gas-distended bowel. CT colonography's (CTC) diagnostic accuracy has been intensively studied, one meta-analysis suggested its sensitivity for established colorectal cancer to be equal to that of SE but having lower sensitivity for small and diminutive polyps [45,46]. Even though diminutive polyps carry small risk of transitioning to invasive cancer, long term effect of using this method as a screening one is not known and theoretically might increase the incidence of interval carcinoma [47]. Further studies will provide more accurate conclusions. MR colonography has the advantage of avoiding the ionizing radiation with diagnostic performances that are promising but heterogenous. It is more demanding considering the patient preparation in comparison to CTC, because except of adequate colonic distension and bowel preparation it requires the use of spasmolytics to reduce bowel movements and motion related artifacts. By now, its results are inferior to same size polyps detection compared to CT colonography, also to colonoscopy. More insight into the optimal technique and associated accuracy measures as well as on cost-effectiveness are needed before it might be considered suitable for colorectal cancer screening [48]. Novel methods are promising, in several studies showing a better adenoma detection rates and tissue characterization when compared to colonoscopy as a gold standard for colorectal cancer screening, having in mind the crucial importance of quality of procedure's performance [49]. 


\section{CONCLUSION}

Because of the immense global burden of colorectal cancer substantial efforts are being invested in development of novel technologies to improve both mucosal observation and tissue characterization and differentiation, consequently to increase adenoma detection rate and decrease the number of biopsies by performing optical diagnosis. Further investigation is needed, but hopefully these innovations with continuous technical improvement might help to reduce the incidence and mortality of colorectal cancer.

\section{References}

[1] Ferlay J, Soerjomataram I, Ervik M, Dikshit R, Eser S, Mathers C, et al. GLOBOCAN 2012 v1. 0, Cancer Incidence and Mortality Worldwide: IARC CancerBase No. 11. Lyon, France: International Agency for Research on Cancer; 2013.

[2] Center MM, Jemal A, Smith RA, Ward E. Worldwide variations in colorectal cancer. CA Cancer J Clin. 2009;59:366-78.

[3] Arnold M, Sierra MS, Laversanne M, Soerjomataram, Jemal A, Freddie B. Global patterns and trends in colorectal cancer incidence and mortality. Gut. 2016; 66(4):683-91.

[4] Schreuders EH, Ruco A, Rabeneck L, Schoen RE, Sung JJY, Young GP, Kuipers EJ. Colorectal cancer screening: a global overview of existing programmes. Gut. 2015;0:1-13

[5] Senore C, Inadomi J, Segnan N, Bellisario C, Hassan C. Optimising colorectal cancer screening acceptance: a review. Gut. 2015;0:1-20.

[6] Leslie A, Carey FA, Pratt NR, Steele RJ. The colorectal adenoma-carcinoma sequence. Br J Surg. 2002; 89(7):845-60.

[7] Inadomi JM. Screening for Colorectal Neoplasia. N Engl J Med. 2017;376:149-56.

[8] Zauber AG, Winawer SJ, O'Brien MJ, Lansdorp-Vogelaar I, van Ballegooijen M, Hankey BF, Shi W, Bond JH, Schapiro M, Panish JF, Stewart ET, Waye JD. Colonoscopic Polypectomy and Long-Term Prevention of Colorectal-Cancer Deaths. N Engl J Med. 2012; 366:687-96.

[9] Nishihara R, Wu K, Lochhead P, Morikawa T, Liao X, Qian ZR, Inamura K, Kim SA, Kuchiba A, Yamauchi M, Imamura Y, Willett WC, Rosner BA, Fuchs CS, Giovannucci E, Ogino S, Chan AT. Long-Term Colorectal-Cancer Incidence and Mortality after Lower Endoscopy. N Engl J Med. 2013;369:1095-105.

[10] Church J. Colonoscopy: What are we missing? Surg Oncol Clin N Am. 2014;23:1-9.

[11] Lebwohl B, Kastrinos F, Glick M, Rosenbaum AJ, Wang T, Neugut AI. The impact of suboptimal bowel preparation on adenoma miss rates and the factors associated with early repeat colonoscopy. Gastrointest Endosc. 2011;6:1207-14.

[12] Singh H. Nugent Z, Demers AA, Bernstein CN. Rate and predictors of early/missed colorectal cancers after colonoscopy in Manitoba: a population based study. Am J Gastroenterol. 2010;105(12):2588-96. 
[13] Matsuda T, Ono A, Sekiguchi M, Fujii T, Saito Y. Advances in image enhancement in colonoscopy for detection of adenomas. Nat Rev Gastroenterol Hepatol. 2017; doi: 10.1038/nrgastro.2017.18

[14] Jang JY. The Past, Present, and Future of Image-Enhanced Endoscopy. Clin Endosc. 2015; 48(6):466-75.

[15] Benedict M, Neto AG, Zhang X. Interval colorectal carcinoma: An unsolved debate. World J Gastroenterol. 2015;21(45):12735-41.

[16] Chaptini L, Laine L. Can I Improve My Adenoma Detection Rate. J Cllin Gastroenterol. 2015;49:270-81.

[17] Fujiya M, Kohgo Y. Image-enhanced endoscopy for the diagnosis of colon neoplasms. Gastrointest Endosc. 2013;77(1):111-8.

[18] Aranda-Hernandez J, Hwang J, Kandel G. Seeing better - Evidence based recommendations on optimizing colonoscopy adenoma detection rate. World J Gastroenterol. 2016;22(5):1767-78.

[19] Ng SC, Tsoi KK, Hirai HW, Lee YT, Wu JC, Sung JJ, Chan FK, Lau JY. The efficacy of capassisted colonoscopy in polyp detection and cecal intubation: a meta analysis of randomized controlled trials. Am J Gastroenterol. 2012;107(8):1165-73.

[20] Biecker E, Floer M, Heinecke A, Strobel P, Bohme R, Schepke M, Meister T. Novel Endocuff-assisted Colonoscopy Significantly Increases the Polyp Detection Rate: A Randomized Controlled Trial. J Clin Gastroenterol. 2015;49(5):413-8.

[21] Floer M, Biecker E, Fitzlaff R, Roming H, Ameis D, Heinecke A, Kunsch S, Ellenrieder V, Strobel P, Schepke M, Meister T. Higher Adenoma Detection Rates with Endocuff-Assisted Colonoscopy - A Randomized Controlled Multicenter Trial. PLoS ONE 9, e114267 (2014).

[22] Waye JD, Heigh RI, Fleischer DE, Leighton JA, Gurudu S, Aldrich LB, Li J, Ramrakhiani S, Edmundowicz SA, Early DS, Jonnalagadda S, Bresalier RS, Kessler WR, Rex DK. A retrograde-viewing device improves detection of adenomas in the colon: a prospective efficacy evaluation (with videos). Gastrointest Endosc. 2010;71(3):551-6.

[23] Rubin M, Bose KP, Kim SH. Successful Deployment and Use of Third Eye Panoramic ${ }^{\mathrm{TM}}$ a Novel Side Viewing Video CAP Fitted on a Standard Colonoscope. Abstract Mo1517. DDW 2014.

[24] Gralnek IM, Siersema PD, Halpern Z, Segol O, Melhem A, Suissa A, Santo E, Sloyer A, Fenster J, Moons LMG, Dik VK, A'Agostino RB, Rex KR. Standard forward-viewing colonoscopy versus full-spectrum endoscopy: an international, multicentre, randomised, tandem colonoscopy trial. Lancet Oncol. 2014;15(3):353-60.

[25] Halpern Z, Gross SA, Gralnek IM, Shpak B, Pochapin M, Hoffman A, Mizrahi M, Rochberger YS, Santo E, Melhem A, Grinshpon R, Pfefer J, Kiesslich R. Comparison of adenoma detection and miss rates between a novel balloon colonoscope and standard colonoscopy: a randomized tandem study. Endoscopy. 2015;47(3):238-44. 
[26] ASGE Technology Committee, Wong Kee Song LM, Adler DG, Chand B, Conway JD, Croffie JM, Disario JA, Mishkin DS, Shah RJ, Somogy L, Tierny WM, Petersen BT. Chromoendoscopy. Gastrointest Endosc. 2007;66(4):639-49.

[27] Stoffel EM, Turgeon DK, Stockwell DH, Normolle DP, Tuck MK, Marcon NE, Baron JA, Bresalier RS, Arber N, Ruffin MT, Syngal S, Brenner DE. Chromoendoscopy Detects More Adenomas than Colonoscopy Using Intensive Inspection without Dye Spraying. Cancer Prev Res 2008;1(7):507-13.

[28] Brown SR, Baraza W, Din S, Riley S. Chromoendoscopa versus conventional endoscopy for the detection of polyps in the colon and rectum. Cochrane Database of Systematic Reviews 2016, Issue 4. Art. No.: CD006439. DOI: 10.1002/14651858.cd006439.pub4

[29] Kahi CJ, Anderson JC, Waxman I, Kessler WR, Imperiale TF, Li X, Rex DK. High-definition chromocolonoscopy vs. high-definition white light colonoscopy for average-risk colorectal cancer screening. Am J Gastroenterol. 2010;105(6):130-7.

[30] Kaminski MF, Hassan C, Bisschops R, Pohl J, Dekker E, Ignjatovic-Wilson A, Hoffman A, Longcroft-Wheaton G, Heresbach D, Dumonceau JM, East JE. Advanced imaging for detection and differentiation of colorectal neoplasia: European Society of Gastrointestinal Endoscopy (ESGE) Guideline. Endoscopy. 2014;46(5):435-49.

[31] Gono K, Obi T, Yamaguchi M, Ohyama N, Machida H, Sano Y, Yoshida S, Hhamamoto $\mathrm{Y}$, Endo T. Appearance of enhanced tissue features in narrow-band endoscopic imaging. J Biomed Opt. 2004;9(3):568-77.

[32] Hayashi N, Tanaka S, Hewett DG, Kaltenbach TR, Sano Y, Ponchon T, Saunders BP, Rex DK, Soetikno RM. Endoscopic prediction of deep submucosal invasive carcinoma: validation of the narrow-band imaging international colorectal endoscopic (NICE) classification. Gastrointest Endosc. 2013;78(4):625-32.

[33] Wanders LK, East JE, Uitentuis SE, Leeflang MM, Dekker E. Diagnostic performance of narrowed spectrum endoscopy, autofluorescence imaging and confocal laser endomicroscopy for optical diagnosis of colonic polyps: a meta analysis. Lancet Oncol. 2013;14(13):1337-47.

[34] ASGE Technology Committee, Abu Dayyeh BK, Thosani N, Konda V, Wallace MB, Rex DK, Chauhan SS, Hwang JH, Komanduri S, Manfredi M, Maple JT, Murat FM, Siddiqui UD, Banerjee S. Technology Committee systematic review and meta-analysis assessing the ASGE PIVI thresholds for adopting real-time endoscopic assessment of the histology of diminutive colorectal polyps. Gastrointest Endosc. 2015;81(3):502.e1-502.e16.

[35] Texeira CR, Torresini RS, Canali C, Figueiredo LF, Mucenic M, Pereira Lima JC, Carballo MT, Saul C, Toneloto EB. Endoscopic classification of the capillary-vessel pattern of colorectal lesions by spectral estimation technology and magnifying zoom imaging. Gastrointest Endosc. 2009; 69(3 Pt 2);750-6.

[36] Kodashima S, Fujishiro M. Novel image-enhanced endoscopy with I-scan technology. World J Gastroenterol. 2010;16(9):1043-9.

[37] Takeuchi Y, Inoue T, Hanaoka N, Higashino K, Iishi H, Chatani R, Hanafusa M, Kizu T, Ishihara R, Tatsuta M, Shimokawa T, Uedo N. Autofluorescence imaging with a trans- 
parent hood for detection of colorectal neoplasms: a prospective, randomized trial. Gastrointest Endosc. 2010;72(5):1006-13.

[38] Ikematsu H, Sakamoto T, Togashi K, Yoshida N, Hisabe T, Kiriyama S, Matsuda K, Hayashi Y, Matsuda T, Osera S, Kaneko K, Utano K, Naito Y, Ishikara H, Kato M, Yoshimura K, Ishikawa H, Yamamoto H, Saito Y. Detectability of colorectal neoplastic lesions using a novel endoscopic system with blue laser imaging: a multicenter randomized controlled trial. Gastrointest Endosc. 2017; pii: S0016-5107(17)30034-2. Doi: 10.1016/j. gie.2017.01.017.

[39] Gheonea DI, Saftoiu A, Siurea T, Popescu C, Georgescu CV, Malos A. Confocal laser endomicroscopy of the colon. J Gastrointestin Liver Dis. 2010;19(2):207-11.

[40] Shukla R, Abidi WM, Richards-Kortum R, Anandasabapathy S. Endoscopic imaging: How far are we from real-time histology? World J Gastrointest Endosc. 2011; 3(10):183-94.

[41] Kudo S, Rubio CA, Teixeira CR, Kashida H, Kogure E. Pit pattern in colorectal neoplasia: endoscopic magnifying view. Endoscopy. 2001;33:367-73.

[42] Nakamura H, Kudo S, Misawa M, Kataoka S, Wakamura K, Hayash T, Kudo T, Mori Y, Takeda K, Ichimasa K, Miyachi H, Katarigi A, Ishida F, Inoue H. Evaluation of microvascular findings of deeply invasive colorectal cancer by endocytoscopy with narrow-band imaging. Endosc Int Open. 2016; 4(12): E1280-E1285

[43] Muguruma N, Tanaka K, Teramae S, Takayama T. Colon capsule endoscopy: toward the future. Clin J Gastroenterol. 2017;10(1):1-6.

[44] Spada C, Pasha SF, Gross SA, Leighton JA, Schnoll-Sussman F, Correale L, Gonzalez Suarez B, Costamagna G, Hassan C. Accuracy of first- and second-generation colon capsules in endoscopic detection of colorectal polyps: a systematic review and meta-analysis. Clin Gastroenterol Hepatol. 2016;14(11):1533-43.

[45] Plumb AA, Obaro A, Fanshave T, Torres US, Baldwin-Cleland R, Halligan S, Burling D. Prevalence and risk factors for post-investigation colorectal cancer ("interval cancer") after computed tomographic colonography: protocol for a systematic review. Syst Rev. 2017;6(1): 36 .

[46] de Haan MC, van Gelder RE, Graser A, Bipat S, Stoker J. Diagnostic value of CT-colonography as compared to colonoscopy in an asymptomatic screening population: a metaanalysis. Eur Radiol. 2011;21(8):1747-63.

[47] Hassan C, Pickhardt PJ, Kim DH, Di Giulio E, Zullo A, Laghi A, et al. Systematic review: distribution of advanced neoplasia according to polyp size at screening colonoscopy. Aliment Pharmacol Ther. 2010;31(2):210-7.

[48] van der Paardt MP, Stoker J. Magnetic resonance colonography for screening and diagnosis of colorectal cancer. Magn Reson Imaging Clin N Am. 2014;22(1):67-83.

[49] Pulanic R, Rustemovic N. Kvaliteta u gastrointestinalnoj endoskopiji. In: Algoritmi u gastrointestinalnoj endoskopiji I endoskopskom ultrazvuku. Medicinska naklada; 2015. 
Sažetak

\section{Novosti u endoskopskoj dijagnostici tumora debelog crijeva}

Karcinom debelog crijeva treći je najčešće dijagnosticiran maligni tumor I četvrti vodeći uzrok smrti od raka na svijetu. Budući da je poznato da većina karcinoma debelog crijeva nastaje malignom alteracijom adenomatonih polipa, razvijeni su brojni programi probira s ciljem povećanja detekcije polipa I karcinoma u ranom stadiju. Kolonoskopija je zlatni standard u dijagnostici kolorektalnog karcinoma. Zbog visokog udjela propuštenih adenoma I slabije mogućnosti diferencijacije benignih od malignih lezija razvijaju se nove endoskopske tehnike s ciljem unaprijeđenja vizualizacije sluznice, sniženja udjela propuštenih adenoma te omogućavanja postavljanja in-vivo optičke dijagnoze. Metode se mogu podijeliti u tri skupine, one koje omogućuju bolju vizualizaciju (ukljućujući kolonoskope sa povećanim opsegom pregleda te korištenje takozvanih 'add-on' uređaja), one koje omogućuju detaljniji pregled I diferencijaciju detektiranih lezija (konvencionalna I virtualna kromoendoskopija, konfokalna laserska endomikroskopija I endocitoskopija), te ostale minimalno invazivne I neinvazivne tehnike.

Daljnja istraživanja s ciljem evaluacije navedenih metoda svakako su potrebna, uz nadu da će njihovo korištenje uz daljnji tehnički napredak pomoći u redukciji incidencije I mortaliteta od kolorektalnog karcinoma.

Ključne riječi: kolorektalni karcinom; dijagnoza; endoskopija; kolonoskopija.

Corresponding author:

Maša Čavlina

e-mail: masa.cavlina@gmail.com 
